\title{
Superego Guilt, Redemption and Atonement in Khaled Hosseini's the Kite Runner
}

\section{Hesham Khadawardi}

\begin{abstract}
The most elaborate theme and which is the central building block in The Kite Runner is that of guilt. ${ }^{l}$ This paper argues that transgression and ultimate transvaluation is essentially the goal of the author, and that, he aims to achieve this through the protagonist, Amir. This theme is closely interwoven with yet another prominent one-the theme of redemption. The starting point of this paper begins with a postulation that the interlocking of these two themes is inseparable since the outcome of redemption is as a result of a choice made hitherto before it. Although a truism that an ominous offence is firstly committed and subsequently followed by some kind of remorse which in this paper is referred to as redemption, the paper examines Amir's characterization and character as a clear manifestation of these recurring motifs. For the purpose to address the aforementioned problems, interrogation is made in this paper at careful understanding of some key issues. For example, in what ways are they (guilt and redemption) manifested? What are the triggers of guilt and subsequent redemption? What is the role of betrayal as harbinger of guilt and redemption? To what extent do interventions by the guilt address the issue of guilt? This paper will attempt to answer these questions. Although there are emerging motifs, such as man's humanity to man, bigotry, master and slave relationships, coming of age, prejudice, this paper will remain focused on betrayal, guilt and redemption.
\end{abstract}

Keywords: Redemption, guilt, betrayal, treachery, atonement, kite-running

\section{INTRODUCTION}

The Kite Runner written by Khaled Hosseini ${ }^{2}$ (2003) an Afghan-American author is probably his most famous work and a masterpiece of antithesis. The novel sold millions of copies worldwide, received critical acclaim and been classified as one of a classic. Among the very few who argue that the novel is not a superior one and that its importance will face away by time is the aging American critic Harold Bloom. Bloom, in this regard argues that The Kite Runner "is a grindingly sincere narrative [here Bloom echoing Oscar Wild's saying "all bad poetry is sincere"] in the shape of a memoir. All of The Kite Runner, "is composed in clichés [...] though I have just compelled myself to read through the book, I cannot regard it as writing" (2009, p. 7). Literary fiction, continues Bloom, "requires mastery of language and its nuances, sustained cognition, skill in characterization" (Ibid). It is a work full of symbols and metaphors. His other works are A Thousand Splendid Suns (2007) and also And the Mountains Echoed (2013) which is his third novel. He was born in Kabul, Afghanistan, in 1965 (Winkler 2007, p. 3). He spent his early years in France where his father was a diplomat in the 1970s.

\footnotetext{
${ }^{1}$ There is, of course, an extensive literature about the theme of guilt in Khaled Hosseini's The Kite Runner. In this article, I draw primarily on my own literature reviews from different scholars and websites. I do not however dwell on it extensively as did other scholars such as Lisa Winkler (2007) A Study Guide to the Riverhead Edition Khaled Hosseini's The Kite Runner. New York: Penguin books. There is also Mishra, Ananya (2011) The "Eternal Loop" of Guilt and the Attempt to Atone in McEwan's Atonement and Hosseini's The Kite Runner, The Oshwald Review: An International Journal of Undergraduate Research and Criticism in the Discipline of English, Vol. 13, No.1; Niraja Saraswat (2014) "Theme of Identity and Redemption in Khaleed [sic] Hossieni's The Kite Runner" International Journal of Interdisciplinary and Multidisciplinary Studies, Vol 1, No.5, pp 166-175 and Nadeem Jahangir Bhat (2015) "Sin and Redemption in Khaled Hosseini's The Kite Runner," The Criterion: An International Journal in English, Vol. 6, No. 2, pp 283-286. Nevertheless, the existing literature on guilt is quite broad and unfocused and like that of Mishra is a comparative analysis.

${ }^{2}$ For a comprehensive biography of Khaled Hosseini, see N. Shamnad (2010) "The Kite Runner by Khaled Hosseini: Historical, Political and Cultural Contexts," published dissertation, University of Kerala; Winkler (2007, pp 3-4); Stuhr (2009) Reading Khaled Hosseini. California: Greenwood Press, pp 1-9) and Bloom 2009, pp 9-10.
} 
His family had to leave to the United States after the Soviet invasion of Afghanistan in 1979. The present paper is concerned with The Kite Runner. The novel is mainly about atonement and redemption. The story starts with a sin committed by the father against Ali (Hassan's father) and other sins committed by Amir against Hassan and it ends up with acts of redemption and atonement by Amir. The Kite Runner is the story of redemption, of atonement, of healing: two sets or rounds of sinning and redemption on a number as stages. At first, audacity, shamelessness and also coarseness in addition to subversiveness are regarded by the guilty as the norm. In his foreword to the $10^{\text {th }}$ anniversary edition of the novel, Hosseini writes, "In these letters [he received from sympathizers and fans all over the world], I see the unique ability fiction has to connect people, and I see how universal some human experiences are: shame, guilt, regret, friendship, love forgiveness, atonement." (KR p. xi). In the first page of the novel (second paragraph) Hosseini writes in a flashback technique "One day last summer, my friend Rahim Khan called me from Pakistan. He asked me to come to see him ... I knew it wasn't just Rahim Khan on the line. It was my past of unatoned sins." $(K R$, p. 1$)$

There are many similarities between the life of Hassan and that of Hosseini himself. In an interview with Hermione Hoby, Hossein stated "My dad was a diplomat and my mum was vice-principal of a high school and now [in America] she's a waitress at Denny's, working the graveyard shift, and my dad is a driving instructor" (Hoby 2013). Bloom (2009, p. 13) states that "Hosseini has also related certain incidents from his life that inspired him to write his book. More specifically, he remembers a family cook he befriended when he was a young boy. Hosseini found out that the cook could not read or write, as prejudice against the Hazara left most uneducated, with no access to schooling." As Foster (2008, p. 67) observes, "Narrators are like cats. They may talk about other people, but the world is mostly about them". A lot of events in The Kite Runner echo the life of Khaled Hosseini. This, however, is not the concern of the present paper. In his introduction to the $10^{\text {th }}$ anniversary of The Kite Runner, Hosseini wrote: "My childhood and Amir's mirrored each other in many ways." (KR, p. x ii) Like his protagonist, Hosseini was brought up in Wazir Akbar Khan area. (KR, p. 4) Similarly, Hassan, Amir began writing his first novel when he was studying at university (p. 181). He finished his first novel in 1988 (KR, p. 182). Like Khaled Hosseini, Amir lived in a big house, his "Baba's mansion", in the capital in Kabul. The house was adorned with "rosebushes" which his father "handpicked from Isfahan," in Iran $(K R$, p. 4). Behind the house, there were "two acres of backyard and rows of cherry trees." (KR, p. 5) In summary, Amir's background can rightfully be regarded as privileged.

\section{MeThodology}

Secondary data was undertaken through desktop review from existing studies, scholarly articles, media features, websites and baselines on The Kite Runner. This continued to provide extensive data on background information on the life in Kabul, Afghanistan and kite running as a sport. My methodology included close and comparative reading of Kite Runner analyses elsewhere from around the world. My key focus was on the thematic patterns of guilt, redemption and atonement and ultimate forgiveness. This process helped me to identify the relationship between the primary nature of sin and how atonement can be exemplified in various ways. I analysed The Kite Runner as the source text and made interrogations from it. Once data was collected it was used to analyse themes, ideas and patterns in the data. Narrative analysis focused on speech and content, such as word usage, meanings of situations, and the social, cultural and political context of the narrative.

\section{RESULTS AND DISCUSSIONS}

Up to this point, I introduced a brief biography of Khaled Hosseini. ${ }^{3}$ In this section, I turn now to the concepts of friendship, betrayal and relationships. I look at how for example Amir's character fails moral test again and again. But we will remiss if I do ignore the cultural significance of kite running. At this junction, I quote Tarzi (2008):

The concept of kite running is aggressively flying your kite and using the glass-coated string to cut the strings of your opponent's kites, the last kite in the air is the winner ... Kite flying is more than a pastime in Afghanistan. It is a cultural obsession. For most of the citizens, inhabiting the city of Kabul, kite running is a form of religious expression. It is a way of the Afghan population to express their country's culture, and at the same time preserve a sense of

\footnotetext{
${ }^{3}$ For a detailed discussion of the life of Hosseini, see Lisa Winkler (2007) A Study Guide to the Riverhead Edition of Khaled Hosseini's The Kite Runner, New York: Penguin Books, p. 3.
} 
honour in the household. The first-born son of a family, typically the oldest is the one who participates in the kite running competition."

However, this sport was completely been banned during the short reign of the Taliban regime. ${ }^{5}$ Kite running as a sport therefore foregrounds my discussion which is divided into different sections; the narrative that results into my thematic concerns come as a result of this sport.

\section{FRIENDSHIP AND BETRAYAL}

From an early age men and boys have been socialized into playing sports to watching sports by many different agents such as family, peers, and school. These agents emphasized that sport was for males and created a situation where sport and masculinity become synonymous (Whisenant, Pederson, and Obenour, 2002). Certainly, one can find examples to buttress their claim. Kite running as a sport also was a show of masculinity. And the point of tension between Amir and Baba is about masculinity. Hassan was an angelic child, a Samaritan. His mother gave birth to him smoothly with the aid of a midwife: "She hadn't needed much help at all because, even in both, Hassan was true to his nature: He was incapable of hurting anyone. A few grunts, a couple of pushes, and out came Hassan. Out he was smiling." (KR, p. 10) Hassan would have done anything for Amir, "Hassan never denied me anything" (KR, p. 4). Hassan's loyalty to Amir is undying. Upon winning the kite running trophy, Hassan told Amir "For you, a thousand times over". Now and then, Amir asked Hassan to shoot walnuts at their neighbours' dog and Hassan should do in spite of the fact that his father (Hassan's) used to scold and punish him for the mistakes he did. The first word Hassan uttered as a little child was 'Amir' (KR, p. 11). When it came to bravery, benevolence and gaming, Hassan superseded Amir in many ways. This was the beginning of an embedded grudge which later I will look within Freudian concept of superego. On one occasion, Hassan and Amir were skimming stones in the lake and "Hassan made his stone to skip eight times" ( $K R$, p.14) while Amir was not able to do the same.

That said, Amir and Hassan, though they had different mothers, were brought up by the same woman, a nursing Hazara woman whom Baba hired to breastfeed Amir and Hassan. Hazaras constitute 9\% of Afghanistan population and are considered to be on the lower end of the economic scale (Shamnad, 2010 , p. 4). ${ }^{6}$ Ali reminded the two kids of their relationship, now that they were being fed by the same woman. "There was a brotherhood between people who had fed from the same breast, a kinship that not even time can break." (KR, p. 11) Winkler $(2007$, p. 3) confirms this statement when he states that, "Though raised in the same household and sharing the same wet nurse, Amir and Hassan grow up in different worlds: Amir is the son of a prominent and wealthy man, while Hassan, the son of Amir's father's servant, is a Hazara".

On his part, Shivram (2013, p. 541) recognizes the importance of the affection established at the breast during infancy which he says was freely acknowledged and lasted until death. He quotes Erik Erikson and says that, "the mouth and the nipple are the mere centres of a general aura of warmth and mutuality which are enjoyed and responded to with relaxation not only by these focal organs, but by both total organism and the mutuality of relaxation thus developed is of prime importance for the first experience of friendly otherness" (ibid). He adds that "wet nurses in fact flourished in times and places of sharp class distinctions" (2013, p. 542).

Looking at the literacy levels, although the role of books and literacy is among the themes in The Kite Runner, here I look at it in the context of friendship. It therefore means that it will not be exhaustively discussed. In spite of the fact that Amir and Hassan lived in the same house for about 12 years, Amir never tried to teach him read; rather he would taunt and mock him for not being able to read. But, in Bamiyan, Hassan was taught to read by a local preacher. On the other hand, Hassan loved Amir so much. One day, he told him "I'd sooner eat dirt ... If you asked, I would ... But I wonder ... Would you ever ask me to do such a thing Amir agha?" (KR, p. 54) "For you a thousand times over!" Hassan

\footnotetext{
${ }^{4}$ See http://teamawesome56.blospot.kr/2007/11/what-is-cultural-significance-of-kite.html?m=1, (accessed 28/5/2016).

${ }^{5}$ Although this paper has avoided the discussion on the banning of kite running by the Taliban, it will be useful to read R. Crew and A. Tarzi's The Taliban and the Crisis of Afghanistan. Massachusetts: Harvard University Press, 2008.

${ }^{6}$ See fn.2 in Shamnad (2010) "The Kite Runner by Khaled Hosseini: Historical, Political and Cultural Contexts".
} 
said to Amir when he was going to bring the kite for him after Amir won the kite-running tournament $(K R$, p. 67). The literacy and the written word is aptly captured, thus:

In the novel, writing is both a dividing force and a uniting one. Amir's wish to be a writer separates him from Baba, who wants him to be athletic and equates his bookishness with his weakness. In Amir's young life, his ability to read and write separates him from Hassan. Because Hassan is a Hazara and expected to remain a servant like Ali before him, no one makes sure he is literate. ${ }^{7}$

In ironic counterpoint, in spite of the fact that the relationship between Amir and Hassan was not an equal footing: Hassan would have done anything to help and protect Amir. Amir used to read stories to Hassan because he could not read (KR, p. 28). Hassan used to address Amir as "Amir agha" or "Amir Sahib." On rare occasions, Amir was so close to Hassan, hugged or kissed him. Hassan did not expect Amir, his master, to be so gentle to him. So one day when Amir kissed him he asked him "What was that for?" Amir replied "You're a prince, Hassan, you're a prince and I love you" (KR, p. 30). Amir was not a brave boy and it was Hassan who defended him whenever he was bullied or attacked by local boys. His father used to complain to Rahim Khan that there was something wrong with Amir "there is something missing in that boy." (KR, p. 22)

At this juncture, I introduce the raping of Hassan. As I look at the sodomization of Hassan, I will use the term "rape". Although most definitions provide an opposite sex explanation of forced sex, in case of Hassan, it was committed by folk of the same sexual orientation. Hassan's rape when the kiterunning tournament came to an end with Amir winning it. McKibbin et al (2008, p. 86) defines rape as "the use of force or threat of force to achieve penile-vaginal penetration of a woman without her consent". He adds that "evolutionary metatheory has been used to generate the hypotheses that sexual coercion and rape occur in species in which males are more aggressive, more eager to mate, more sexually assertive, and less discriminating in choosing a mate" (McKibbin, 2008, p. 87). Hassan got the kite but he was blocked by Assef and two other boys (Wali and Kamal) from going back home with the kite. Assef and his friends offered not to hurt Hassan if he hands them the kite, but he rejected the deal "Amir agha won the tournament and I ran this kite for him,' Hassan told Assef and his friends $(K R, \mathrm{p} .72)$. When Hassan refused to hand over the kite to them Assef raped him (KR pp 75-76). Son of a wealthy Afghan pilot and a German mother, Assef was a notorious boy who bullied and tortured other boys in the borough. Whenever Assef came across Hassan he would mock and abuse him. Assef was a racist who hated Hazaras and wanted them out of his "homeland". He told Amir that he hates him because he is a friend of a Hazara (KR, p. 4). ${ }^{8}$ Shamnad (2010, p. 9) describes Assef as "a sadistic and sociopathic teenager and the main antagonist. He is a killer and a paedophile and above all a supremacist racist. Assef taunted Hassan for refusing to hand him the kite:

But before you sacrifice yourself for him, think about this: would he do the same for you? Have you ever wondered why he never includes you in the games when he has guests? Why he only plays with you when no one else is around? I'll tell you why, Hazara. Because to him, you're nothing but an ugly pet. Something he can play with when he's bored, something he can kick when he's angry. Don't ever fool yourself and think you're something more.' ( $K R$, p.72)

As has been shown in the aforementioned quotation, just before the rape, Hassan mentally transforms into a hero and stands his ground. This symbolism became the epic building block of guilt on the part of Amir. Considering this fact, it is easy to understand the torment and tumultuous torture Amir underwent subsequently after the rape ordeal. This was the beginning of Amir's guilt and disgust for

\footnotetext{
${ }^{7}$ See http://www.gradesaver.com/the-kite-runner/study-guide/themes, an article that discusses The Kite Runner themes. For the topic on literacy, see especially "Literacy and the Written Word" in the said article.

${ }^{8}$ The Kite Runner brings into light the bad blood that has resulted into chronic ethnic profiling and discrimination in Afghanistan and especially between the Pashtuns and those of Hazara. The Hazaras are viewed as inferior compared to the Pashtuns. When they were in power, the Talibans discriminated against the Hazaras to an unprecedented level. For more on the anti-Hazara discrimination in Afghanistan, see Mer Hekmatullah Sadat, "Historical Background of Afghanistan" in Lisa Winker (2007) A Study Guide to Khaled Hosseini's The Kite Runner. New York: Penguin, pp 4-5 and Crew and Tarzi's The Taliban and the Crisis of Afghanistan, especially pp 31-32.
} 
the sins he committed against Hassan, the disgust emanating from a person whom he shared breast milk with and whom he chose to abandon at his hour of need.

At this point, I want to go further and discuss treachery and psychological effects of rape which are hallmarks of betrayal. Treachery is characterized by faithlessness or readiness to betray trust. In The Kite Runner, the protagonist betrays his best friend. Amir is presumed to have put a wall surrounding Hassan against the aggression of Assef. The abandonment of Hassan in the alleyway is the height of this betrayal. Earlier, Amir, in an attempt to separate himself from Hassan and disassociate himself from the guilt, prepares a mischievous scheme with the aim of getting rid of Hassan and hence of the burden that is making his life miserable. He put forward a proposal to his father to kick out Ali and Hassan. Conversely, his father rebuffed him and notified him of his intention to let the two be permanent residents in his household. It will be useful to give a background of this trajectory. The absurdity of this chronology of events is when Amir schemes to get rid of Hassan. When Ali and Hassan left their shaft and went to buy shopping, he sneaked into Hassan's room and concealed his new watch and some cash under Hassan's mattress. Hassan was the main suspect and Amir's father brought them all together. When Hassan was confronted, to everyone's astonishment, he acknowledged being the culprit. Baba understood that Hassan never engaged in misdemeanour. Amir believed that Hassan's action was mitigated by circumstances of love to him from Hassan. He came to the realization that Hassan knew that Amir watched him when he was being raped by Assef. He could no longer share the same place with him since this tormented him to an unprecedented level. That is why Hassan sacrificed himself for his friend:

Hassan knew I'd seen everything in that alley, that I stood there and done nothing. He knew I had betrayed him and yet he was rescuing me once again, maybe for the last time. I loved him in that moment, loved him more than I'd ever loved anyone, and I wanted to tell them all that I was the snake in the grass, the monster in the lake. I wasn't worthy of this sacrifice. I was a liar, a cheat, and a thief." $(K R, \mathrm{p} .105)$

To Amir's surprise, Baba forgave Hassan and asked Ali (Hassan's father) not to leave the house. Amir was nonplussed by this forgiveness. His father believed that theft was an abomination. The following excerpt aptly captures this:

Forgive? But theft was the one unforgivable sin, the common denominator of all sins. When you kill a man, you steal a life. You steal his wife's right to a husband, rob his children of a father. When you tell a lie, you steal someone's right to the truth. When you cheat, you steal the right to fairness. There is no act more wretched than stealing.... and if Baba could forgive that, then why couldn't he forgive me for not being the son he'd always wanted?" (KR, p. 106).

Tomkins (1987, p. 137) and many other psychiatrists state that shame is one of the primal instinctive human reactions. According to Tomkins (ibid), shame could cause distress, fear, shame/humiliation, disgust, anger, and the so called dismal. Amir suffered the same.

Instances of forgiveness spread across the novel. For example: "Bakhshida. Forgiven. It's done." His voice dropped a little. Again: "Except Baba stunned me by saying, "I forgive you." (KR, p. 105) The concept of forgiveness is central to The Kite Runner. Amir is engulfed and surrounded solidly by indiscretions he had suffered before. He embarks on a painful journey of redeeming himself from this torture and metal chains tied to his feet. Amir must make an attempt to forgive himself. This forgiveness is closely tied to atonement. It is a psychological remedy. It has a placebo effect on Amir. He creates a situation where he receives some punishment from his erstwhile enemy Assef, which subsequently, in Amir's view, makes him take some form of punishment on behalf of Hassan. At last, he finds remedy. Elsewhere, Soraya Taheri (Amir's wife) had a fling with a young Afghan when the family was in Virginia years before the couple had met. When she was eighteen years old, Soraya ran away with an Afghani man and stayed with him for one month. Her father knew her whereabouts and forced her to come back home. When she can back home, she found that her mother suffered from a stroke (because she was so ashamed that her daughter eloped) and "the right side of her face was paralyzed." (KR, p. 164) Soraya insisted on telling Amir her story before accepting to marry him. She told him it is up to him to make a decision on their matrimony. Amir came to compare Soraya's attitude and her courage to his cowardness. He says:

I envied her. Her secret was out. Spoken. Dealt with. I opened my month and almost told her how I'd betrayed Hassan, lied, driven him out, and destroyed a forty-year relationship 
between Baba and Ali. But I didn't. I suspected there were many ways in which Soraya

Taheri was a better person than me. Courage was just one of them. (KR, p. 165)

After they married, Soraya said to Amir that she thought that he will refuse to marry her after telling him about her earlier affair 'I'm so lucky to have found you. You're so different from every Afghan guy I've met .... I think a big part of the reason why I did not care about Soraya's past was that I had one of my own. I knew all about regret." (KR, p. 180) The following section will partially recap the narrative of the behaviour of Amir to kick out Hassan from their home. But I will give psychological arguments and counter-arguments of the same.

\section{InSIDE Amir's (Post-Traumatic STRESS Disorder)) PTSD AND AFFlictions}

Mishra (2011, p. 65) states that:

The great tragedies carry in them an overwhelming sense of guilt: the unbearable guilt of incest in Sophocles' Oedipus Rex and the guilt of murder in Shakespeare's Hamlet and Dostoevsky's Crime and Punishment. The sense of guilt the protagonists felt owing to a crime committed at some point in their adulthood changes the course of their lives. It either brings about their downfall or they spend the rest of their lifetime trying to find redemption.

Agony and distress is central to this paper. The torment that Amir undergoes causes him untold anguish. After seeing Hassan being raped by Assef, Amir was tormented because he did not help or even tried to help him, "I watched Hassan get raped", Amir recalls. This resulted in him being an "insomniac" ( $K R$, p. 86). Often after an episode like this, victims may experience Post-traumatic stress disorder (PTSD), feelings of severe anxiety and stress, depression, flashbacks memories of rape as if it is taking place again, borderline personality disorder, sleep disorders or eating disorders, dissociative identity disorder, guilt, distrust of others - uneasy in every social situations, anger and feelings of personal powerlessness - victims feel the rapist robbed them of control over their bodies. ${ }^{9}$ After being raped by Assef, Hassan stopped seeing or playing with Amir as often as he did in the past. Instead, he tended to sleep more and more; he found refuge in sleeping more hours, as Ali (Hassan's father) told Amir. Ali was anxious about the well-being of his son and hence wanted to get answers for his questions from Amir. On his turn, Hassan no longer did his home chores next to Amir when he was having his meals. Rather, he avoided being close to Amir. For about two weeks they did not even speak to each other. After a few months later, Amir inclined to avoid being with Hassan as well, since this kept reminding him of the crime committed against Hassan and how helpless he was being unable to defend him. "I'd hear Hassan shuffling around the kitchen in the morning, hear the clinking of silverware, the whistle of the teapot. I'd wait to hear the door shut and only then I would walk down to eat." $(K R$, p. 87$)$

To recap my earlier discussion, a few months after the rape incident, Hassan wanted to "rekindle things" between him and Amir but the latter shunned him. One day Hassan asked Amir "I don't know what I've done, Amir agha. I wish you'd tell me. I don't know why we didn't play anymore" but Amir told him off and asked him to stop "harassing" him. (KR, p. 88) What is more is that Amir suggested to his rather (Baba) to hire "new servants" but his Baba was firm in refusing Amir's proposal. Baba replied to Amir:

I grew up with Ali ... My father took him in, he loved Ali like his own son. Forty goddamn years Ali's been with my family ... and you think I'm just going to throw him out? ... I've never laid a hand on you, Amir, but you ever say that again ... You bring me shame. And Hassan ... Hassan is not going anywhere, do you understand?" ( $K R$, pp 89-90)

Sigmund Freud (1962, p. 71) in Civilization and Its Discontents notes: "To begin with, if we ask how a person comes to have a sense of guilt, we arrive at an answer which cannot be disputed: a person feels guilty (devout people would say sinful) when he does something he knows to be 'bad"'. Mishra (2011, p. 74) adds that, "we feel guilty because we have a conscience, a conscience dictated by a set of moral values set before us. In a child, this conscience or, as Freud says, superego, is in the developing stage when he/she is gradually internalizing certain controls upon him/herself." He says

\footnotetext{
${ }^{9}$ See an article by Samantha Gluck (2015) on the Effects of Rape: Psychological and Physical Effects of Rape, available online: www.healthyplace.com/abuse/rape/effects-of-rape-psychological-and-physical-effects-of-rape.
} 
that it is because of the inability to morally gauge his action that Amir's reaction to his crime is initially confused and extreme. There is a possibility of a subconscious grudge. For awhile, Amir was jealous because of the favouritism that Hassan got from Baba. In the narrative that Baba tells Rahim Khan about Amir's cowardice and how he was rescued in several occasions by Hassan, Amir's reaction is caustic and antagonistic towards Hassan. Elsewhere, Erik Erikson (1987, p. 231) rehearses this in his book Childhood and Society when he says, "The superego of the child is primitive, cruel and uncompromising as may be observed in instances where children over-control and over-constrict themselves". Amir himself finds himself in a transition. He is twelve-years old between childhood and adolescent stage. He has insecurities as indicated earlier on because his father finds him wanting in his masculinity.

\section{Atonement And REDEMPtion}

Reparation for a wrong can be a tumultuous affair and heart wrenching. It is about reconciliation and expiation of sin. It is a way of seeking justice. Atonement brings some relief and peace especially when believing strongly that a new journey, a new beginning towards peace is commencing. The whole point of Amir is to aspire to bring Hassan back to his fold. Amir understands his sin, his guilt for him to come closer to Hassan again. The atonement is the ultimate price that Amir intends to pay Hassan. Amir told Hassan off and asked him to stop harassing him. Amir then, says "I wish he would give it right back to me, break the door open and tell me of- it would have made things easier, better." $(K R$, p. 88). Later, when Amir and Hassan went out together for the first time after the rape incident, Amir again provoked Hassan so that the latter could retaliate and this would have eased his psychological pressure burdening Amir but he did not. Amir asked Hassan to hit him back but he did not, "I wished he'd give me the punishment I craved so maybe I'd finally sleep at night. Maybe then things could return to how they used to be between us" (KR, p. 92). But of course Hassan did not make any retaliation leaving Amir extremely frustrated to the core: "But Hassan did nothing as I pelted him again and again. "You're a coward!" I said. "Nothing but a goddamn coward!" (ibid). It is Amir's cowardice that his father is concerned about when he confides in Rahim Khan that it is strength of will that is "missing" in Amir. He is unable to defend not only himself but also his friend, fearing he would get hurt instead.

Ironically, Hassan might have tolerated insults and attacks directed towards him or members of his family. For example, his father (Ali), mother (Sanaubar), wife (Farzana) all of whom suffered humiliation and insults by the Pashtun ruling majority or Taliban. However, he never tolerated an insult or injury against Amir or his father. Hassan kept silent when Taliban soldiers cursed him and his father in addition to beating his wife. As a Hazara weak citizen, Hassan tolerated all these insults so that he and his family might escape ill-treatment by the aggressive Taliban. But when it came to Amir or Amir's father, Hassan could have risked it all for his friend. That is why when he and Amir were kids, Hassan exposed himself to risk, was humiliated or even hit by Assef and his friends when they mocked them; he sacrificed himself for the one whom he took as his best friend, Amir. On one occasion, Assef and friends mocked both of them with Hassan getting the biggest share of insults. He was raped by Assef for defending Amir's kite but never let them take it. Incidentally, the only time we see Hassan as a coward (as he mentioned in the letter he sent to Amir) was the time his wife was beaten by the Taliban officers. The incident which took place at the market (bazar) is appropriately captured. In a letter Hassan wrote to Amir, Hassan never met Amir nor did he have any contact with him after the latter left to America, but Hassan wrote the letter hoping that Amir would read one day, we read:

The other day, I accompanied Farzana jan (his wife) to the bazaar to buy some potatoes and naan. She asked the vendor how much the potatoes cost, but he did not hear, I think he had a deaf ear. So she asked louder and suddenly a young Talib ran over and hit her on the thighs with his wooden stick. HE struck her so hard she fell down ... If I fought, that dog would have surely put a bullet in me and gladly! Then what would happen to my Sohrab? The streets are full enough already of hungry orphans and every day I thank Allah that I am alive, not because I fear death, but because my wife has a husband and my son is not an orphan." $(K R, \mathrm{p}$. 216)

This is the only time we see Hassan the coward not Hassan the brave who used to defend his friend, Amir, repeatedly. This scenario of being in a powerless state almost akin to 'cowardice' is a concrete example of Hassan's innocence of succumbing to mistreatment. It could be argued that Hassan found 
himself in a situation which he could not comprehend. He makes a positive attempt to avoid the temptation of compromising his security and that of his wife. At this point, overwhelmed by the love to his wife, he metamorphoses to "Hassan the coward" justifiably so nevertheless. This notion of "Hassan the coward" is Khadawardi's argument; it is a temporary persona to fend off antagonists. It is an action that might draw a mixture of pity and condemnation. The full scope of his action sinks when we see him and his wife safe from the bazar. He has obviously saved a potentially tragic situation from the Talibans.

Lawrason (2015), in his article The Kite Runner: Redemption, provides a definition of redemption stating that the dictionary classifies it as "to free from what distresses or harms, to get or win back, to free from the consequences of sin, to change for the better, to atone for/ offset a negative effect". ${ }^{10}$ The protagonist attempts to atone for the sins and mistakes committed by him and his father. His father had an illegal relationship with the wife of his servant (Ali) and the result was an illegal child (Hassan) whom he (for cultural considerations, for the benefit of Hassan himself) did not acknowledge as a legitimate son. Hassan was raised in appalling conditions. As well, he atoned for his cowardness, when his friend Hassan was raped by Assef and his gang. Later, he takes the child (Hassan's son, Sohrab) to America to raise him over there. "In The Kite Runner, redemption is so important because sin is so enduring. Amir opens the story by telling us not about how exactly he sinned, but about sin's endurance". ${ }^{11}$

In order to follow up the above, I briefly foreground characterization, focusing especially on Rahim Khan and Sanaubar. But before that, it is important to understand the societal characteristics of the Pashtuns. ${ }^{12}$ Pashtuns love to suffer alone when they have some calamities or illnesses. Baba and Rahim Khan are exemplary in this regard. Rahim Khan, diagnosed with cancer and had only a short period to live, leaves a letter to Amir (whom he asked to go to Kabul to bring Sohrab) in which he states "As for me, it is time to go. I have little time left and I wish to spend it alone. Please do not look for me. That is my final request for you" (KR, p. 302). In 1990, Sanaubar (Ali's wife) gave birth to Hassan in 1964. She did not hold her new-born child in her hands neither did she care to even touch him. Less than a week from giving birth to Hassan, Sanaubar, taunted Ali "There ... Now you have your own idiot child to do all your smiling for you!" (KR, p. 10). She even refused to hold or kiss the child; five days later she eloped. (ibid) It would be helpful here to state that by eloping, although Sanaubar went against social imperative, this peculiar action was influenced by several internal factors that enabled her take that direction. Similar to classical tragedies, she had the ambivalent feeling of facing the wrath of societal ethos and the fury of Ali. The above quotation emphasizes the gloomy nature of things facing Hassan. After many years Sanaubar comes back to the same house where she gave birth to Hassan more than thirty eight years ago, she left in 1964 and returned back in 1990. Initially, Hassan refuses to listen or speak to her but she implores: "I have walked long and far to see if you are as beautiful in the flesh as you are in my dreams. And you are. Even more ... You smiled coming out of me, did anyone tell you? And I would not even hold you. Allah forgive me, I wouldn't even hold you." (KR, p. 210)

In his turn, Rahim Khan telephoned Amir from Pakistan, in 2001. Rahim was critically ill- about to die. He knew all the secrets Amir thought nobody has ever known: Hassan's rape by Assef, the watch and money Amir tossed under Hassan's mattress. Rahim asked Amir to come to Pakistan to amend his mistakes. He told Amir, "Come. There is a way to be good again" $(K R$, p. 192). When he came to Pakistan, Rahim told him all about his past and that Hassan is his brother. Rahim Khan told Amir that he wanted him to go himself to Kabul and bring back Sohrab (Hassan's son) to safety in Peshawar. Amir replied that Kabul is a dangerous place to go to and that he could pay for someone else to do the job if it is a matter of money. Rahim gets angry and tells Amir that it is not a matter of money. Rahim could have hired someone to do this job but he wanted Amir to do it so that he might atone his sins. But he wanted him to atone for the sins he committed as a child against Hassan. Rahim told Amir that

\footnotetext{
${ }^{10}$ See Emily Lawrason (2015) The Kite Runner: Redemption. Available online, https://prezi.com/m/ntkz128przyh/the-kite-runner-redemption, accessed on 13/05/2016.

${ }^{11}$ See http://www.gradesaver.com/the-kite-runner/study-guide/themes, an article that discusses The Kite Runner themes. For the topic on redemption, see especially "Sin and Redemption" in the said article.

${ }^{12}$ See fn. 6 that states that Pashtuns are the dominant ethnic group in Afghanistan because they are the presumed major population in Shamnad (2010) "The Kite Runner by Khaled Hosseini: Historical, Political and Cultural Contexts".
} 
Ali was 'sterile' and that Hassan was not his son, its Baba's. Ali married another woman before Sanaubar (Hassan's mother) and they lived together for three years but the woman left him and married another man and she bore him three kids. Rahim and Baba knew that Hassan was not Ali's son. When Amir knew this via Rahim Khan he shouted angrily at him "You bastards! ... All of you, you bunch of lying goddamn bastards!" (KR, p. 222) Rahim tried to cool Amir down. He explained to him met it wouldn't have been easy, according to Afghani culture, to tell him. People would talk and this would have destroyed everything, including Hassan's life. Amir left Rahim Khan and went alone to a coffee shop in Peshawar. Amir was thinking of what has gone wrong, his father. He came to realize that he is not much different from his father, that both of them sinned and committed grievous sins against these whom they loved "Baba and I were more alike than I'd ever known. We had both betrayed the people who would have given their lives for us. And with that came this realization: that Rahim Khan had summoned me here to atone not just for my sins but for Baba's too." (KR, p. 226)

On this way from Peshawar to Kabul, Amir stopped at Farid's brother house for the night. He was offered food which he shared with Farid. Amir noticed that one of Wahid's son was looking steadily on Amir's digital wrist watch. He asked Wahid- in line with Afghan culture- to give his son a gift and the father reluctantly agreed. Metaphorically, the gift Amir gave to the boy was a wristwatch, the same trick he used to get rid of Hassan when they were kids, as if he wanted to clear himself from the sin he committed as a child.

Amir went to the house of a leading Taliban (Assef) where Sohrab had to dance for Taliban leaders. Assef threatened to kill Amir or charge or treason (p. 278). Assef (as did Farid later) asked Amir if he really came back from America to Kabul for a 'Hazara' ( $K R$, p. 285). Then, Assef challenges Amir $(K R$, p. 278) and advised his guards 'When it's all done, only one of us will walk out of this room alive ... If it's him [Amir], then he's earned his freedom and you let him pass ..." (KR, p. 287). After verbal altercation with Amir, Assef decides to have a duel with Amir, declaring that only one winner can leave the room. Assef brutally assaults Amir and the latter bleads heavily and suffers serious bruises and injuries but he never fought Assef back. In the same way, Hassan did not fight him back when he was hitting him with pomegranates on the hill. To fully redeem himself and atone for all his sins (he committed against Hassan \& Ali). Hassan felt at peace receiving Assef's blows and swears and he never fought back; he was even laughing. This is a clear sign that Amir paid Hassan back but this time to Hassan but to his little son, Sohrab. In other words, if the young Amir watched his friend when he was being raped by Assef and his gang the little Sohrab watched the mature Amir being severely hit by Assef and the former did not fight back as if he wanted to redeem himself from guilt. But, while Amir did not defend his friend (and brother) Hassan gainst Assef's assault, Hassan's son (Sohrab) came to the rescue of Amir and shot Assef with his slingshot. Amir recounts this as follows:

I laughed because I saw that, in some hidden nook in a corner of my mind, I'd even been looking forward to this. I remembered the day on the hill I had pelted Hassan with pomegranates and tried to provoke him. He'd just stood then, doing nothing, red juice soaking through his shirt like blood. Then he'd take the pomegranate from my hand, crushed it against his forehead. Are you satisfied now? He'd hissed. Do you feel better? I hadn't been happy and I hadn't felt better, not all at. But I did now. My body was broken .... But I felt healed. Healed at last. I laughed. (p. 289)

To Amir's good luck, Sohrab (Hassan's son) interferes and saves Amir's life in the same way his father had done about thirty years ago. Sohrab asked Assef to stop "hurting" Amir but arrogant and bashful Assef felt humiliated by the threat of a "Hazara" boy and rushed to crush the little boy but Sohrab let his slingshot go and a brass ball rested in Assef's eyes.

In the final round of redeeming himself, back in America, one day Amir was having dinner his inlaws, his father-in-law asked Amir to tell him about the "Hazara boy" whom he brought with him from Afghanistan reasoning "I have to deal with the [Afghani] community's perception of our family. People will ask. They will want to know why there is a Hazara boy living with our daughter. What do I tell them? (KR, p. 360) Rapidly, Amir angrily and forcefully replied, in a final bid of atonement for his and father's past; their guilt:

"It's all right... You see, General Sahib, my father slept with his servant's wide. She born him a son, named Hassan. Hassan is dead now. That boy sleeping on the couch is Hassan's son. 
He is my nephew. That is what you tell people when they ask ... And are more thing, General Sahib ... You will never again refer to him as 'Hazara boy' in my presence. He has a name and it's Sohrab". (KR, p. 361)

Amir's father (Baba) had to an extent redeemed his sins. Amir described his father as being "an unusual Afghan father, a liberal who had lived by his own rules, a maverick who had disregarded or embraced societal customs as he has seen fit." ( $K R$, p.180) Early in the story, maybe due to a guilty state of mind he had, Baba [Amir's father] hired the same nursing Hazara woman who had fed Amir to feed Hassan as well, after his mother's elopement only a few days after his birth. (KR, p. 11) "Baba hired the same nursing woman who had fed me to nurse Hassan." (KR, p. 11) Baba used to buy birthday gifts for Hassan, and Amir: "Baba never missed Hassan's birthday" (KR, p. 44). On one occasion, 1979, Baba brought an India plastic-surgeon to fix Hassan's upper lip. In one of the few junctures that Baba showed direct kindness towards Hassan, Baba "patted Hassan on the back. Even he put his arm around his shoulder" (KR, p.14). Baba built an orphanage for homeless and poor children. Amir describes how his father worked hard during the construction of the building; as he wanted to repent his sins of having an illegal relationship with Ali's wife (Sanaubar). Again, in the final act of benevolence before leaving Afghanistan, Baba risked his life to save the honour of an Afghani woman whom a Russian soldier wanted to rape in exchange for allowing them to pass the Afghani-Pakistani borders. Baba interfered telling Karim (the driver) to ask the Russian soldier to stop but the soldier replies that "this is war. There is no shame in war." $(K R, \mathrm{p} .115)$ The soldier and pulled the trigger and threatened to kill Baba but a senior officer interfered and all have safety.

In America, when Amir passed his high school exams and was ready to join university next year, his father was so happy and they celebrated his birthday. Baba said: "I wish Hassan had been with us today" (KR, p.133) Amir's father was suffering; he was torn between his love for Amir (his legitimate son) and Hassan (his illegitimate son). Amir lived in his father's house and enjoyed a luxurious life. But Hassan, on the other hand, lived in the shed with poor Ali. What is more is that Hassan served as a servant for Amir, preparing his food, clearing his shoes and ironing his clothes for him. That is why Amir's father was always tough on Amir and kind towards Hassan. Rahim Khan told Amir (in a letter) that his father was torn. In a letter to Amir, Rahim Khan told him that he father was torn between his live for Hassan and Amir. (p. 301) That is why he was trying to redeem himself: building an orphanage, giving money to the poor (p. 302)

Rahim Khan and Sanaubar also repented and felt remorse for the sins they committed. When he was young, Rahim Khan was in love with a beautiful Hazara young woman (Homaira) but his family rejected this match and even threatened to kill him. (KR, p. 99) Homaria was the daughter of one of servants of Rahim Khan's neighbours. Homaria's family was banished from the city. Rahim told Amir "She would have suffered. My family would have never accepted her as an equal. You don't order someone to polish your shaves one day and call them "sister' the next" (KR, p. 99). After spending about four decades away from his family, Sanaubar returns back home and asks her son (Hassan) to forgive her. At the beginning Hassan did not want to forgive his mother but later he did and the whole family lived in peace for a few years before Taliban wreak havoc on them. To conclude here, the theme of redemption, as has been suggested earlier, is part and parcel of The Kite Runner. The hero of novel tries to atone for the sins and mistakes committed by him and his father. His father had an illegal relationship with the wife of his servant, Ali, and the result was an illegal child (Hassan) whom he did not acknowledge as a legitimate son. Hasan was raised in appalling conditions. As well, he atoned for his cowardness, when his friend Hassan was raped by Assef and his gang. Later, he takes the child to America to raise him over there.

\section{CONCluSion}

Through discussing the themes of redemption, atonement and guilt, this paper has examined the effects of these on the main characters in The Kite Runner. The evidence from their actions showed that actions (like betrayal of a friend) pose significant negative spillover effects on both the victim and the one committing the sin. The relations between the protagonist Amir and Hassan changes from a mutual one to that of adversity while the former makes every effort to get an atonement to escape vilification. Amir shows great commitment (in his own way) to be exonerated from past sin.

The Kite Runner is, of course, a fictionalization. But - as with so many events that followed the entry of the Taliban in the Afghanistan, in my view is that it can neither be characterized as accurate or 
inaccurate because not all facts are known. Nevertheless, Khaled Hosseini in his characterization aptly captures and acknowledges universality of human experiences like shame, guilt, regret, friendship, love, forgiveness and atonement. The author himself makes a confession and says how his life mirrors that of Amir and that fiction can affect readers and even the writer himself. In this regard, the novel can be read as an indictment. But however it is read, the novel is an essential record of an important part of Afghanistan history.

We have seen that atonement, redemption and forgiveness took a long time to be achieved. The expectations always related to the logical relationship between the accused and the accuser. It is reminiscent as variables for peace and peace treaties. As much as Amir tried to bring Hassan closer to him, there existed a climate of suspicion. I already mentioned the psychological effects of rape and how Hassan was affected. Following that tragic episode, there was no clear normalization of relations between them. The scope of all Amir's efforts did not have immediate positive results. There is definite absence of confidence on the part of the victim of rape. This is related to many reasons, among them are the internal cultural structures of Afghanistan. Any step toward rebuilding trust between Amir and Hassan was entrenched in setbacks.

\section{REFERENCES}

Bhat, Nadeem Jahangir (2015). "Sin and Redemption in Khaled Hosseini's The Kite Runner," The Criterion: An International Journal in English, Vol. 6, No. 2, pp 283-286.

Bloom, Harold (ed.) (2009) Khaled Hosseini's The Kite Runner. New York: Infobase Publishing.

Crews, Robert D. and Tarzi, Amin (eds.) (2008). The Taliban and the Crisis of Afghanistan. Massachusetts: Harvard University Press.

Erikson, Erik (1987). Childhood and Society. London: Paladin Grafton Books.

Foster, Thomas (2008). How to Read Novels Like a Professor. New York. Harper.

Freud, Sigmund (1962). Civilization and Its Discontents. New York: W.W. Norton.

Gluck, Samantha (2015). Effects of Rape: Psychological and Physical Effects of Rape online: www.healthyplace.com/abuse/rape/effects-of-rape-psychological-and-physical-effects-of-rape/, (accessed on 29/5/2016).

Hoby, Hermione (2013). "Khaled Hosseini: 'If I could go back now, I'd take The Kite Runner apart"'. The Guardian, https://www.theguardian.com/books/2013/jun/01/khaled-hosseini-kiterunner-interview, accessed on 20/01/2017.

Hosseini, Khaled (2013). The Kite Runner. New York: Penguin, first published 2003.

Lawrason, Emily (2015). The Kite Runner: Redemption, https://prezi.com/m/ntkz128przyh/the-kiterunner-redemption/, (accessed on 29/5/2016).

Mishra, Ananya (2011). The "Eternal Loop" of Guilt and the Attempt to Atone in McEwan's Atonement and Hosseini's The Kite Runner. The Oshwald Review: An International Journal of Undergraduate Research and Criticism in the Discipline of English. Vol. 13: No.1, pp 65-88.

McKibbin, William et al (2008). "Why Do Men Rape? An Evolutionary Psychological Perspective," Review of General Psychology. Vol.12, No. 1, pp 86-97.

Noor, Ronny (2004). "The Kite Runner". World Literature Today,78 (3/4): 148, doi:10.2307/40158 636.

Paraveen, Tarana (2015). Unveiling Political and Personal Turmoil: "The Kite Runner" by Khaled Hosseini," International Journal of English Language, Literature and Translation Studies, Vol. 2, No. 2, pp 109-122.

Sadat, Mer Hekmatullah ((2007). "Historical Background of Afghanistan" in Lisa Winker (2007) A Study Guide to Khaled Hosseini's the Kite Runner. New York: Penguin.

Saraswat, Niraja (2014) "Theme of Identity and Redemption in Khaleed [sic] Hossieni's The Kite Runner" International Journal of Interdisciplinary and Multidisciplinary Studies, Vol 1, No.5, pp 166-175.

Shamnad, N (2010). "The Kite Runner by Khaled Hosseini: Historical, Political and Cultural Contexts," Published dissertation, University of Kerala.

Shivram, Balkrishan (2013) "Nurslings, Milk and Moral Development: A Case Study of Imperial Mughal" in Asian Journal of Social Sciences \& Humanities. Vol. 2, No. 2, pp 541-547. 
Stuhr, Rebecca (2009). Reading Khaled Hosseini. California: Greenwood Press.

Tarzi Robert (2008). The Taliban and the Crisis of Afghanistan. Massachusetts: Harvard University Press.

Tomkins, Silvan (1987). "Shame” in Donald L. Nathanson's The Many Faces of Shame. New York: Guilford.

Whisenant, W. A., Pederson, P. M., and Obenour, B. L. (2002). "Success and gender: Determining the rate of advancement for intercollegiate athletic directors" Sex Roles, Vol. 47, No.9, pp 485-491.

Winkler, Lisa (2007). A Study Guide to the Riverhead Edition Khaled Hosseini's The Kite Runner. New York: Penguin books. 